\title{
Social licence, corporate social responsibility and coal seam gas: framing the new political dynamics of contestation
}

Keywords: social licence, corporate social responsibility, unconventional gas, coal seam gas, democracy framing

\begin{abstract}
This paper explores the contestation dynamics between the unconventional gas mining sector and its challengers through the prism of the social licence to operate. Social licence is a dominant narrative in the mining sector today and as a signifier of the sector's CSR credentials, the term is an influential one. Its capacity to confer project legitimacy, and hence avoid the risks of community opposition, helps explain why most companies seek to gain one. Today both gas proponents and opponents talk the language of social licence: the former to defend their projects, the latter to challenge them. Yet, beyond rhetoric, the precise meaning of social licence remains elusive. This paper uses a case study of community opposition to primarily coal seam gas projects in an eastern Australian region to explore how the absence of a precise meaning for social licence has created a strategic opportunity space for the industry's opponents to invest social licence with a potent democracy frame. This democracy framing has proved particularly effective as a contestation tool and helps explain the outcomes in this case.
\end{abstract}

\section{Introduction}


Corporate Social Responsibility (CSR) is a prominent feature of today's corporate environment (Dunphy et al., 2014).The expectation that companies extend their responsibilities beyond shareholder value is now well embedded in the community at large. These social responsibilities are wide in scope, but responsibility for the impact that corporations have on communities and the environment are core features of the contemporary CSR landscape. In the increasingly transparent world that modern communication technologies enable, suspect corporate behaviour that was once well hidden from view is now more likely to be exposed, threatening a corporation's legitimacy and reputation, which can in turn impact profits. CSR, broadly understood, represents a way of managing the increasing accountability pressures on modern corporations, helping them to maintain their legitimacy in a highly competitive market place where brand and reputation can 'make or break' them. Most corporations today will hence go to considerable effort to market themselves as good corporate citizens (Reinhardt and Stavins, 2010; Forbes and Jermier, 2010). Through showcasing their 'social contract' credentials, CSR, particularly through the social licence frame, offers corporations a way forward in today's challenging operating environment.

Social licence is now a well-established narrative in the corporate world but its uptake has been particularly extensive in the mining sector. As a signifier of the sector's CSR credentials, especially in a sector long beset with controversy, the term is a powerful one. Its capacity to confer project legitimacy, and hence avoid the financial and reputational risks of community opposition, helps explain why most companies will seek to gain one. But today both proponents and opponents talk the language of social licence: the former to defend their projects, the latter to contest them. This is because social licence is very different from a legal one, treating legal and regulatory approvals as a first step in the legitimation process, with consent and approval from community stakeholders sealing it. While this was not necessarily its corporate intent, social licence has today triggered a politically charged contestation 
dynamic that, under certain conditions, can derail a company's operational legitimacy and its development plans.

This paper examines these contemporary social licence dynamics, focusing on how social licence is increasingly used as the prism through which both the defence and contestation of mining projects occurs. In particular, it examines how external stakeholders such as impacted communities opposed to mining projects in their region, utilise social licence as a (counter)strategy to shape their contestation politics. Using a case study of sustained community contestation of unconventional gas developments in a regional area in eastern Australia to illustrate its argument, the paper recounts how civil society's strategic utilisation of a social licence discourse promoted by the mining sector itself, has provided a useful tactic in project contestation. It maintains that this tactic's effectiveness derives from the contestants' rendering of social licence as an essentially political concept by interpreting it through a potent democracy 'frame' that resonates deeply with affected communities (see Benford and Snow, 2000). Mining companies generally employ the notion of social licence as a process-driven measure that renders the community engagement required of it under its legal licence conditions as largely a communicative device for informing the affected communities of its plans. Its contestants deploy it more politically. They emphasise the notion's fundamentally political character by directly linking it to democratic norms that most of the community hold dear, and that directly implicate governments in the process. Understood this way, rather than becalming the industry's contestation, as is often the CSR intent of social licence, it can instead inflame it.

The paper begins with a quick overview of unconventional gas developments globally and in Australia before turning to a discussion of the social licence concept, particularly as it functions in the mining sector. It then presents the case study of proposed unconventional gas projects, particularly coal seam gas (CSG), in the Northern Rivers area of northern New 
South Wales, Australia, highlighting the contest between the industry and the community over what social licence means, how such a licence is won and the political implications of an absence of social licence. This analysis tells us a good deal about the social licence notion itself, the context of CSR in which it sits, and the overarching political and policy dynamics which it can generate. Overall, this paper seeks to contribute to a still relatively small but developing political analysis literature of CSR's notion of social licence. In addition, through its employment of a framing lens to help analyse the political dynamics in the case study, the paper seeks to demonstrate the continued utility of collective action frames in helping to explain successful mobilisations.

\section{Unconventional Gas}

The gas industry is burgeoning, both in Australia and worldwide. Taking advantage of its albeit contested- status as less emissions intensive than coal, today gas is quickly establishing itself as the transitional fuel of the future (see Hausfather, 2015). According to the International Energy Agency (IEA 2012: 10) we are currently experiencing a 'golden age of gas', with the fuel's current 25 per cent contribution to the energy mix expected to eclipse coal production by 2035. Much of this industry has been concentrated in conventional gas production. However, over the last few years technological developments and exploration expansion has positioned unconventional gas as the stellar performer in the gas market worldwide.

\subsection{Unconventional gas in the United States and Europe}

The United States, considered 'the birthplace of the unconventional gas revolution' (IEA, 2012: 101), is undergoing a shale gas boom with gas providing the country with around half 
of it domestic gas supplies (IEA, 2015). While in operation for a number of decades, recent technological developments, particularly hydraulic fracking, have helped steer the United States gas industry to relative boom proportions. The country enjoys a plentiful supply of all three main unconventional gas sources - tight gas, coalbed methane and shale. Deposits are widely distributed geographically with states such as Texas and Pennsylvania enjoying ample reserves. According to the International Energy Agency, as of 2002, the country holds the capacity for a further 100 production years (2014: 2). Most of this increased production is projected to derive from the Marcellus and Haynesville formations - two of the United States' largest plays and among some of the largest gas fields in the world (IEA, 2014: 2).

While generally welcoming the economic and energy security benefits the industry provides, the unconventional gas industry has courted considerable controversy (see Spence, 2013; Davis, 2012). The growing opposition has tested the industry's overarching political support, prompting some state governments and political parties to revise some of their gas policies. These responses include bans or moratoriums on exploration and production in some states, the application of stricter regulations such as expanded buffer zones, and pauses in the issuing of new licences (see Hauter, 2013).

Much of the opposition to the shale gas boom in the United States has centred around a negative view of 'fracking'. Evensen et al (2014) discuss the increasingly controversial and negative connotations that the word 'fracking' evokes. In particular, they chronicle the significant impact that the negative framing of the word has had on shaping the anti-shale gas opposition in the United States, especially in the Marcellus Shale region in the states of New York and Pennsylvania. They observe that the word's 'multiple meanings' creates linguistic confusion which in turn opens up an opportunity space for anti-fracking discourse. In the 
hands of the industry's opponents the word has thus been broadened beyond its technical scope and wielded as a 'weapon' in the unconventional gas 'culture wars' (2014: 130).

While some European countries may nurture an energy independence dream similar to the United States, Europe has undertaken limited unconventional gas exploration, even as the scoping for technologically feasible reserves is gradually increasing (Spencer et al., 2014, p. 28). Estimates vary but it is generally considered that Poland, Romania and France boast some of the largest reserves, with Denmark, the United Kingdom and Sweden hosting smaller ones (Spencer et al., 2014: 29; see also Johnson and Boersma, 2013). The uptake of European exploration has been slow, for a variety of reasons. Strong public opposition has seen France instigate outright bans, despite its considerable reserves (IEA, 2012, p. 125); bans they share with countries such as Bulgaria, the Czech Republic, the Netherlands and parts of Germany. The geological conditions for gas mining in Europe are also not always promising. As Spencer et al (2014, pp. 29-30) points out, European shale tends to be deeper and smaller; there is more limited labour availability; it has a more densely populated continent and problematic property rights; and, generally, more stringent environmental regulations (see also (Johnson and Boersma, 2013: 391; IEA, 2012: 122-3).

The industry's potential in Europe should not be dismissed altogether, however. Poland is keen to explore its gas mining's possibilities and reduce its reliance on Russian gas (IEA, 2012: 124). Despite this ambition, and a relative absence of community opposition, the reality of gas exploration and production remains a long way off (Johnson and Boersma 2013, p. 397). The United Kingdom is also a keen supporter of the industry, with a parliamentary inquiry in 2011 concluding that a well regulated industry could benefit the country's economy considerably (IEA, 2012: 127-8). Not all Britons shared the then 
Cameron government's enthusiasm however. In their overview of shale gas discourse in Britain, Cotton et al. (2014) find that the government has disproportionately highlighted the economic and energy security benefits of the industry at the expense of environmental and community concerns. Despite this, Jaspal and Nerlich (2014) observe that the anti-gas opposition in the United Kingdom has launched a successful counter campaign based on competing 'social representations' of fracking. Mirroring the experience in the United States, they single out the potency of the 'threat, danger and risk' representations of fracking in swaying the public against unconventional gas as an acceptable energy source.

\subsection{Unconventional gas in Australia}

In Australia, while offshore gas remains the largest contributor, unconventional gas mining is increasing notably (Wood and Carter, 2013). As in the United States, this rise is largely attributable to the technological innovations that have significantly facilitated the extraction of the gas. Much of the Australian unconventional gas activity centres on CSG but shale and tight gas resources are gradually increasing their market share. CSG production has nonetheless been well underway in the Australian state of Queensland since the 1990s, with the gas making a major contribution to the state's domestic gas supplies. However, the Queensland unconventional gas industry has largely operated in sparsely populated areas, well away from the urban-rural fringe. Its relative isolation and lighter population density has limited its visibility and opposition, hence rendering the Queensland industry relatively uncontroversial - until more recently. Our case study, however, sits in a very different geographical setting, which helps explain, in part, the case's trajectory. 
Unconventional gas' rise is not universally welcomed, and is contested, in Australia and globally, on several main grounds - depending on the type of gas involved. Shale gas, tight gas and CSG, or coalbed methane, use different extraction and production methods, generating different issues and concerns (Australian Government 2015b; IEA, 2012, pp. 289). CSR and social licence responses are hence necessarily geared towards the specificities of these different processes. While shale, tight and coalbed gas are all generally extracted from low permeability reservoirs, shale and tight gas are usually extracted from considerably greater depths than coal seam gas which is located closer to the surface (IEA, 2012, p. 28; Spence, 2013, p. 6). Shale and tight gas hence rely significantly on hydraulic fracturing, or fracking, while CSG extraction's reliance on fracking varies depending on the resistance of the targeted seam (Cham, 2014). The different property rights regimes in the United States and Australia require that companies develop different community engagement approaches to negotiate access to relevant landholdings.

There are nonetheless a number of shared concerns across the different types of unconventional gas. The first is unconventional gas' extensive footprint which, as the IEA (2012: 18) observes, is 'not just in [its] size but also in [its] wide geographical distribution which is in marked contrast to the concentration of conventional resources'. This is unproblematic when the mining is located in isolated environments, but when it emerges in more populated areas its clusters of densely spread multiple wells can generate visible discomfort (see Goldenberg, 2013). For communities so impacted the industry can become a highly tangible physical presence. On a political level, the legal impotence of individuals and communities to deny the industry access to their properties and communities has generated considerable angst among affected landholders (see Lock the Gate, 2016). Indeed, in Australia, the reality that private property rights do not extend to sub-surface minerals, which 
governments own, comes as a surprise to many landholders. With most Australian governments supporters of the industry (Australian Government 2015a, 2015b), communities can feel that their concerns are unheeded, in turn contributing to the perception of a growing democratic deficit whereby governments are more attuned to corporate ambitions than constituents' interests (see ABC, 2015; Dobney, 2014). These two factors alone contribute to unconventional gas' perceived 'undemocratic' character. These factors are reinforced, however, by a number of other specific concerns.

Widespread unease over the environmental impact of drilling and fracking on the water table and water quality is central to these concerns (IEA, 2012: 30-38). Water is a contentious issue in unconventional gas mining - whether tight, shale or coal seam gas. In its 'Golden Rules' or recommended CSR and social licence best practice, the IEA (2012: 10) considers that '[r]igorous assessment and monitoring of water requirements (for shale and tight gas), of the quality of produced water (for coalbed methane) and of waste water for all types of unconventional gas' is critical to the broad range acceptance of gas mining. The scale and spread of unconventional gas mining exacerbates these and other extraction concerns. For CSG, these risks include the volume of produced water, the 'connectivity' of coal seams and aquifers, the aquifer's 'recharge' rate, and the duration of the mining as a whole (IEA, 2012, p. 36). Given that extraction occurs relatively close to the surface in CSG mining, a key concern becomes aquifer contamination or geological disturbance (IEA, 2012 p. 133). By contrast, shale gas extraction uses large volumes of water, particularly during the fracking. This water usage proves contentious in areas with water shortages, as well as risking the lowering of water tables; in addition, the frequency of water transportation throughout a mining region intensifies community disturbance (IEA, 2012, pp. 30-2). 
For impacted communities, the socio-cultural impacts are equally discomfiting (see Measham et al., 2016). There is first, as we saw, the visual impact of numerous wells scattered over extensive tracks of the landscape (see Goldenberg, 2013). When the impacts of increased truck traffic, busier roads, construction and production noise, and increased airborne pollutants are added, the community's distress can increase considerably (see IEA, 2012: 22; Spence, 2013: 2, 8; Goldenberg, 2013). The community's seeming legal impotence to challenge such developments fuels their anguish, which helps explain the name of one of the key organisations challenging the industry: the 'Lock the Gate' alliance.

Moreover, for some community members their very livelihoods and agricultural identities feel threatened by an industry that seemingly disregards both (see Colvin et al., 2015). Many consider that gas mining takes precedence over farming, often with the full blessing of governments (see Dobney, 2014; Goldenberg, 2013). With their economic and socio-cultural viability seemingly threatened, many agricultural communities hence feel both abandoned and diminished. While, historically, mining and farming have co-existed relatively harmoniously in both Australia and the United States, the pace and scale of the gas 'boom', has upset this balance. In addition, unconventional gas' extensive geographical footprint means that projects are no longer confined to relatively remote regions (IEA, 2012: 19-20). Communities thus increasingly question the continued efficacy of their way of life, their democratic rights, the alleged 'collusion' between governments and the gas industry, and the political legitimacy of industrial operations that seemingly privilege the rights of one section of the population over another.

Finally, the unconventional gas industry's contribution to greenhouse gas emissions reinforces the mounting opposition to it. Unconventional gas can generate more production- 
related, or fugitive, emissions (largely composed of methane) than conventional gas when the full production cycle is taken into account (IEA, 2012: 38). These concerns heighten the broader unease about gas' role as a transitional fuel in the era of climate change (Hausfather, 2015). As the IEA (2012: 40) points out, the '[d]ifferent assumptions about the level and impact of methane emissions can have a profound effect on the perception of gas as a “cleaner" fuel' (see also Howarth et al., 2011; Santos and Maher, 2012). Altogether, these concerns question the gas industry's continued social legitimacy to operate. Its legal licence may be well established but its social licence is not.

\section{Conceptualising social licence}

Social licence has been a feature of the mining sector for well over a decade. A response to past disasters, conflicts and challenges, social licence was seen as a way to better manage the mining sector's social and environmental responsibilities, hence protecting the industry's reputation and legitimacy (see O'Faircheallaigh, 2013). By addressing public demands for higher transparency and accountability standards, and greater community input into projects that impact them, social licence helps operationalise CSR in the mining industry (see Kuch et al., 2013; Moffat and Zhang, 2013; Owen and Kemp, 2013; Bice and Moffat, 2014). Indeed, social licence goes to the heart of CSR's beyond compliance approach (Gunningham et al., 2004: 308). It showcases companies' transformed approaches to sustainable development, a transformation that is buttressed by a expanded social responsibility ethos.

In an age of CSR, social licence thus acts as a form of strategic risk management for most major companies. Its objective is to protect companies' financial and reputational assets by proactively anticipating and managing contestation rather than simply reacting to it. 
Understood this way, a social licence - at least from a corporate perspective - can be seen as 'a pragmatic calculation' designed to minimise risk by undertaking strategic forms of community engagement (Owen and Kemp, 2013: 31). It is for these reasons that social licence is 'increasingly becoming a core component of business activity for resource companies in Australia' and across the world (Kuch et al., 2013: 5), and a new standard in today's commercial environment (Raufflet et al., 2014; IEA, 2012; Gunningham et al., 2004).

Most companies are aware that their social obligations are quite separate to their legal ones, recognising that legal approvals only go a part of the way towards guaranteeing social ones (Gunningham et al., 2004). A social licence to operate acknowledges that a legal licence is a necessary but not sufficient step in the pursuit of mining project approval. The additional steps are articulated in social licence terms. These include community consultation and engagement processes that respect the community's views and that are buttressed by robust scientific studies that allay public concerns. A social licence implies that, in the face of public challenges, the industry does not simply fall back on the project's legal standing to proceed.

While social licence is now the prism through which many contemporary mining developments are negotiated, companies vary significantly in their responses to this new corporate responsibility landscape (see O'Faircheallaigh, 2013). Governments, like corporations, become entangled in social licence's web in ways they do not always welcome. Aside from their agency over legal licencing and regulatory conditions, the community engagement that underpins social licence strays into government's political territory. Members of communities that challenge social licence are also constituents with whom governments have a direct democratic relationship - at least in modern democracies. When 
they are seen to fail to adequately press companies to fulfil their social licence obligations governments too can become the active targets of community discontent. For impacted communities, distinctions between legal and social licences can blur, replaced by more resonant 'social contract' norms.

Australia's preeminent mining industry association - the Minerals Council of Australia openly acknowledges that the social licence is 'an unwritten social contract'; indeed,

... unless a company earns that licence, and maintains it on the basis of good performance on the ground, and community trust, there will undoubtedly be negative implications. Communities may seek to block project developments; employees may choose to work for a company that is a better corporate citizen; and projects may be subject to ongoing legal challenge, even after regulatory permits have been obtained, potentially halting project development (MCA, 2005: 2).

The idea that a social licence is earned or 'won', and that it is largely the 'gift' of the community, is an important one. The Council clearly distinguishes between legal requirements and 'social contract' ones, and acknowledges that those that 'confer' the social licence are generally the communities that are impacted by the company's activities (see also Prno, 2013).

A social licence nonetheless remains just that - a social and not legal licence - and in the absence of clear definitions and mandatory conditions, its applied meaning can vary significantly. It can, in short, be made to mean what different actors wish it to mean - hence the meaning and framing attached to social licence becomes strategically salient. Companies 
lay claim to having earned it, and communities having 'conferred' it, in a number of ways. As we observe in our case, companies often emphasise process; that is, to having conducted community consultation as was required of them, even if the outcome was far from satisfactory - for both parties. Unlike legal licence, which needs to meet very specific and often measurable requirements, companies can still assert their social licence rights and continue to operate even when the community deems they do not hold one. Here their legal licence carries significantly more weight. For communities, however, while a social licence is not established legally, it is determined in the 'court of public opinion' - and the norms that resonate there. When the winning of social licence proves difficult, companies respond in different ways. Some will re-double their efforts to gain community approval, while others will remain adamant that they have one, since they followed due process. Here, as we will observe in our case, they will re-emphasise their legal licence, demand government respect it, and highlight the unreasonableness of an unduly antagonistic community.

While there are not universally agreed 'textbook' definitions of social licence - which underpins the dispute we will shortly narrate - it does incorporate critical components. Most research identifies transparency, trust and 'genuine' community engagement as central - even as these are open to definitional controversy (see IEA, 2012). Prno (2013: 584-5) also finds that 'unique combinations' of local social, economic and environmental factors influence the community response to specific mining projects, and that mutually respectful relations between the company and communities are key to both the winning and retaining of a social licence (see also Colvin et al 2015). Importantly, a sense of fairness in the spread of benefits and costs of local projects, and the engagement processes that underpin decision making, are also pivotal (Prno 2013: 586-7). Moffat and Zhang (2013: 61) emphasise the community's trust in the company for the securing of a social licence (see also Hodge, 2014). They observe 
that this trust is made up of two interrelated elements: integrity-based trust ('which relates to the trustor's perception that the trustee is adhering to a set of principles') and competencebased trust ('that refers to the trustor's view that the trustee ... has the skills and knowledge necessary to manage the particular issues of interest to the trustor or community') (Moffat and Zhang, 2013: 62; see also Boutilier and Thomson, 2011).

The International Energy Agency has perhaps gone furthest in its naming of the specific conditions necessary for attaining the community's trust and hence winning social licence, which they label the 'Golden Rules' (IEA, 2012). These seven rules refer to the sufficiency and robustness of baseline studies; careful site selection and monitoring; the prevention of leaks; the responsible treatment of water; minimisation of emissions; commitment to a high level of environmental performance; and focused attention on the cumulative economic, social and environmental impacts (IEA, 2012: 13-5). A distillation of social licence analysis hence highlights several interrelated core principles, all centred on the notions of trust and legitimacy, and effective community engagement.

\section{The Case Study}

This section utilises elements of a collective action framing lens - a key framework in the social movements literature (Goffman 1974; Benford and Snow, 2000) - to analyse the developments and outcomes in the case study. It contends that a 'democracy frame' has proved particularly effective in challenging the perceived 'intrusion' of unconventional gas

mining in the case study's region, allowing - through the conduit of social licence - for a potent democracy discourse to take root. 
The case draws its empirical material from a number of sources. It utilises a range of primary documents - including company reports, media releases, media reports, personal correspondence and court transcripts. In addition, it has sourced a broad range of publicly available interviews with key actors in organisations involved in the case. This includes several interviews with the CEO of the main company involved in the case, Metgasco; key actors in the main non-government organisations opposing the industry - particularly the Lock the Gate Alliance and the Gasfield Free Northern Rivers groups; and various community actors. Consistent with the democracy frame the paper utilises to analyse the case, the paper's methods consisted of searching the interviews, media releases and media reports for specific terms such as democracy, citizen rights, community rights, and constituents, and for the construction of arguments thematically centred on the political rights afforded citizens of a democratic state.

Before proceeding to the case, a brief discussion the phenomenon of framing is presented. Social movements - an identity the anti-CSG mobilisation has long claimed to hold (see Ricketts, 2012) - have regularly utilised their values as the underpinnings of their contestation (Ingelhart 1977, 1990). But it is not simply the values per se but the meaning assigned to them that ultimately dives contestation (della Porta and Diani, 2006, p. 87). The strategic communication of meaning has underpinned various movements' success, particularly when it is clearly directed to 'specific orientations of the sectors of public opinion which [social movements] wish to mobilise' (della Porta \& Diani, 2006, p. 73); Bedford and Snow, 2000). Framing thus considers how social movements actors create and communicate meaning, particularly through the narratives they construct in prosecuting their oppositional cases (see Snow, 2013). 
According to Benford \& Snow (2000, p. 612) 'framing processes have come to be regarded, alongside resource mobilization and political opportunity processes, as a central dynamic' in the politics of mobilisation. Key framing tasks include 'diagnostic framing', or problem identification and its social construction; 'prognostic framing', or solution proposals and contestation plans; and 'motivational framing', or the shaping of call to arms incentives (Benford and Snow, 2000, pp. 615-8; see also della Porta \& Diani, 2006, pp. 74-79). Spence (2013, p. 4) points to the overarching 'moral' or 'ethical' framing of the anti-fracking debate, contending that 'opponents of fracking has generally framed their arguments in moral or ethical terms, calling shale gas production a "nightmare". We see evidence of each of these processes in our case.

\subsection{The regional context}

The Northern Rivers region, situated in the far north east Australian state of New South Wales (NSW), comprises a diverse and distinctive community of almost 300,000 people. The area is renowned for its natural beauty which includes world heritage forests, iconic coastal regions and picturesque towns. While tourism is a flourishing industry in the area, its main industries also include dairy farming, fishing, forestry and a variety of different agricultural enterprises, both boutique and larger scale. A considerable influx of alternative lifestyle seekers several decades ago swelled the area's population of largely long-standing farming communities and towns. More recently, the population has been boosted by a 'sea- and treechange' urban middle class, many of whom migrated from Australia's major cities. This demographic, particularly the early alternative constituency and the more recent urban arrivals, has contributed to the region's reputation for its progressive values and political literacy, forged - for the early alternative constituency at least - by its participation is some 
of the most well organised and iconic environmental battles in Australia's history (see Hutton and Connors 1999). While historically a conservative National Party stronghold, the Northern Rivers region thus also contains a considerable left-leaning constituency with environmentalist sympathies. Indeed, in the 2015 New South Wales state election, the Greens Party was successful in winning one seat (Ballina) and came very close to winning another (Lismore). This was a significant win in an area long recognised as National Party heartland. Much of this electoral success was attributable to the large scale opposition, across ideological lines, to unconventional gas mining in the region.

As in many other parts of Australia, exploration licences for unconventional gas, especially CSG, in the Northern Rivers region have been held by several mining companies for up to two decades, with some companies active in the region since 2008. Metgasco, Dart Energy, Arrow Energy and Clarence Valley Resources, for example, participated in exploratory drilling for coal seam and tight sands gas in a number of locations. But it was the drilling of a well in the region's Keerong Valley in 2010 that prompted widespread awareness of the gas industry's plans for the region and launched the local anti-unconventional gas campaign (GFNR, 2015). By this time a more critical eye had been trained on unconventional gas projects worldwide, particularly in the United States, reinforced by the documentary Gasland in 2010 which highlighted the negative impacts of the unconventional gas 'revolution' in the United States.

Metgasco's plans to expand its wells near the township of Casino at a site called Doubtful Creek triggered widespread community opposition that culminated in its withdrawal there in March 2013 (see GFNR, 2015). The company did not cite community opposition as a reason for its withdrawal, however, preferring to focus on the introduction of new state 
government policies that created expanded buffer zones and stricter operational conditions (in response to widespread anti-gas opposition through New South Wales). At the time Metgasco claimed that it had little choice but to suspend 'field operations when the NSW government announced major changes to regulatory and administrative procedures' (Metgasco, 2013). The company nonetheless planned to resume operations in 2014 when the policy conditions were more favourable, at a location called the Rosella Well at Bentley - the site of the upcoming dispute.

\subsection{The Bentley Blockade}

Armed with its legal licence, and the associated environmental assessment approvals, Metgasco proceeded to organise for exploratory drilling of a new well on a consenting farmer's land in Bentley, near Lismore. In an effort to deflect the negative image of CSG mining, the company emphasised that its search was for tight gas rather than CSG. However, this did little to deter the mounting opposition. The campaign drew on the large number of supporters throughout the region and beyond. This included not only the 'usual suspects' alleged 'professional' protestors from the realms of the 'hippy' unemployed - but also a diverse range of farmers, food producers, small business owners, environmentalists, professionals and 'ordinary' members of the community. The routine corporate strategy of de-legitimising such contestants as 'professional' protestors was hence diminished.

With majority community support, a large and well organised contingent of mining opponents gathered on the border of the proposed site, establishing a highly visible 'tent city' of opponents. During critical times - for example, when the company was planning to move its equipment on site - opponent numbers swelled considerably (CSGFNR, 2014b). This 
included community members for whom such protests were a new and novel experience, and who had never envisaged that they would be participants in such enterprises. Indeed the community's case for the company's lack of a social licence was based in large part on the near-unanimity of this diverse opposition, as formally measured by a 2012 exit poll ${ }^{1}$ administered by the Australian Electoral Commission during local government elections in Lismore; and buttressed by the Gasfield Free Community surveys conducted by member of the community (see GFNR, 2016; Sledge, 2016). The scene was hence set for a prolonged resistance to the proposed mining at Bentley. Instead, to the surprise of both the company and its contestants, the case took an unexpected turn.

In May 2014, the NSW government suddenly intervened by suspending Metgasco's legal licence to operate. Its justification for doing so is particularly important. The government charged in effect that the company lacked a social licence, claiming that it 'did not fulfil a condition of its exploration licence, namely to undertake genuine and effective consultation with the community as required' (in Nicholls, 2014). Behind the scenes, however, an altogether different explanation held sway. NSW was at the cusp of a state election and it stood to lose at least two seats in the Northern Rivers as a result of the widespread opposition - across party lines - to the region's gas plans (see Robertson, 2015). The suspension's intention was fundamentally directed to becalming a highly volatile preelection climate. This turn of events was nonetheless much celebrated in the anti-CSG community, even as most understood well the political pragmatism that drove it. Despite this, the significance and implications of the suspension are not to be discounted. By casting the

\footnotetext{
${ }^{1}$ An exit poll was conducted in the region's largest city of Lismore during its 2012 local government elections. The poll was administered by Australia's main electoral body - the Australian Electoral Commission - and allowed 97.2 per cent of eligible voters to vote on the CSG poll. Using 'established methods developed for post election analysis, it found that from the 4.2 per cent of participants randomly selected, 13.1 per cent voting yes to CSG in their area and 86.9 per cent voting no (see Luke and Lloyd, 2013: 2).
} 
imbroglio in direct social licence terms, the government had cemented social licence's political status, acknowledging the grounds on which the community was making its oppositional case, and using these same grounds for halting the project. This was a development which the mining industry's contestants would go on to reinforce to considerable strategic effect. As one Greens party MP commented, the anti-CSG 'blockade is a physical manifestation of the social licence and shows that a social licence is not only real, but necessary for an industry like coal seam gas to operate' (in Nicholls, 2014). While this may not have been its intent, by casting social licence as 'real', the government had transformed it into a much more tangible contestation tool. At this point at least the company's plans were hence derailed. But, undeterred, it proceeded to challenge this decision in the courts, as we discuss subsequently.

\section{Acquiring Social Licence}

A central point of contention in social licence discourse in how it is acquired. Answers to this question in turn centre on how it is understood, which can vary considerably between industry, governments and community actors. This understanding gap creates fertile territory for meaning creation by relevant actors. Perhaps more contentiously, the question highlights the link, if any, between social licence processes - the conduct of community consultation and engagement - and the outcome of those processes. This raises the highly controversial issue of what the appropriate course of action should be when social licence processes, even when conducted according to the letter of legal licence law, do not result in convincing the community to support the project and it remains staunchly opposed. Such continued opposition directly targets governments, highlighting their role in negotiating fraught social licence politics cast in respected democratic terms. 


\subsection{The company and social licence}

Metgasco recognised long ago that it would need a social as well as legal licence to operate if it was to undertake a successful enterprise in the region (in Honan, 2011). But the suspension decision, and the community's protracted opposition, revealed that social licence, rather than being simply a routine 'box ticking' exercise, could actually derail projects. Metgasco charged that it had well established social licence mechanisms such as a comprehensive community relations policy and a raft of environmental commitments. Its community relations policy states that '[s] upporting our communities will encourage support of our business'; to this end '[g]ood communication is essential to good community relations' and '[o]pen and honest communications are essential to credibility and trust' (Metgasco, 2014a). Metgasco is also committed to 'to minimising environmental impacts from our business activities', including ‘[e]nhancing Metgasco’s environmental awareness and performance by means of induction, consultation, hazard identification and management, incident reporting and training' (Metgasco, 2014b). Metgasco also points to what it claims is the successful operation of the gas industry in many other locations, including the United States and Queensland, as evidence of the Northern Rivers' trenchant opposition as the exception to rather than the rule (Metgasco, 2014c).

Essentially, however, for Metgasco the winning of a social licence relied directly on having acquitted its obligations on community consultation as required by its legal licence conditions. Moreover, its CEO claims that '... we did a good job at community consultation. We followed the government's guidelines to the letter ... We've followed all our licence obligations, we've behaved by the law; we've done the right thing'; indeed, 'we [need to] 
clarify what consultation means and what it doesn't mean. Consultation cannot mean that you have to persuade everybody in an area to support a project'. Throughout, Metgasco thus claims to have faithfully acquitted the community consultation obligations on which its social licence depends. In letter to the office of the NSW Minister for Resources and Energy, Metgasco outlines the specific consultation steps it has engaged in, including its community, landholder and local council briefings, advertisements, website updates (Metgasco, 2014c). Furthermore, in making these community engagement claims, the company had the courts on its side.

The company had challenged the 2014 suspension of its legal licence by the NSW government in the NSW Supreme Court, which it won in 2015 - albeit on procedural fairness grounds outside the direct ambit of social licence arguments (see Supreme Court NSW 2015). Nonetheless, the judgment was pertinent for what it had to say about the status and meaning of social licence. Metgasco had argued that, contrary to the government's charges, it had legally acquitted its community consultation obligations. From a different perspective, the Court agreed with it, observing that in the face of the limited guidelines for community consultation specified in its legal licence, the company had ostensibly addressed what was required of it. Importantly, however, the Court raised the issue of what 'effective consultation' as prescribed by legal licence requirements actually meant, separating effective consultation processes from consultation outcomes:

63. As one would expect from their nature, the guidelines are not prescriptive and admit of a degree of flexibility depending upon the circumstances. They have the tone of constructive suggestions rather than firm commands. And construing them as a whole, their reference to "effective consultation" to my mind focuses on the quality of the process of consultation, rather than on any outcome whereby the persons who are 
the focus of the consultation are persuaded by it (Supreme Court NSW, 2015: point $63)$.

In short, in the absence of more prescriptive definitions of community consultation, whose guidelines, the Court noted, 'have the tone of constructive suggestions rather than firm commands' and which, furthermore, do not distinguish between the process of the consultation and its outcome, the company could certainly make a case that it had acquitted its processional obligations here. Importantly, the Court observed that the consultation guidelines provided no guidance as to what exactly 'effective consultation' constituted. Paradoxically perhaps, it was the government which had expanded on the notion of community consultation, tending towards a qualitative definition - a definition the industry's contestants would discursively build on. In its rationale for suspending the licence in the first place it highlighted Metgasco's inadequate community consultation program; its limited scope; its 'defeatist attitude' to consultation; its failure to address technological concerns; and its lack of skilled negotiators (Supreme Court NSW, 2015: point 23). This represented a considerable 'list' of community consultation inadequacies on the part of the company, which added more concrete specificity to what the contested notion of social licence actually meant.

\subsection{The community and social licence}

The community embraced the government's suspension and social licence logic but took it further. While they welcomed the government's preparedness to list some social licence attributes, they took the opportunity to give social licence even more concrete meaning, 
particularly by framing the social licences deficiencies identified by the government itself in a broad democracy frame. The community was primarily concerned with how to proceed when the outcome of the consultation process proved unsatisfactory and did not win its endorsement. The consultation required under social licence could succeed in convincing the community of the net benefits of the proposed project - or otherwise. If otherwise - as was the case here - it was clear to this community that the industry had failed to gain its social licence. The contentious question of how to proceed hence came to the fore. For the company to continue operating in the face of such widespread opposition carried with it the risk of exposing social licence as rhetorical vacuity, which reflected poorly on both the company and on government. This was particularly so when the community's stance was buttressed by extensive community engagement and consultation of its own which revealed that a significant majority in the region, across political and cultural divides, opposed the project and did not accord it a social licence. Moreover, the extent of the opposition was measured through conventional and respected methodologies - electoral polling undertaken by the Electoral Commission - which, for the community, added considerable democratic legitimacy to the results. As one spokesperson for the opposing Lock the Gate alliance observed: the 'massive groundswell of majority public opinion' is the determinant of social licence, or otherwise (Galliard, 2012). To ignore this, is to 'continue to dismiss the evidence of overwhelming public opposition in the region', and, by implication, of democratic processes (Galliard, 2013).

For the community, the opposition to gas mining was constituted in direct social licence terms from the outset: on a lack of trust in the safety, environmental integrity and economic benefits claimed by the company, and dismissal of its largely ceremonial community consultation process. Moreover, it contended that when gas companies 
demonstrate 'that they cannot be trusted' landholders should have 'the right ... to reject gas drilling on their land across the state' (Guise 2014). In a lengthy letter to Metgasco's CEO, one community contestant distinguished between a legal and social licence: 'Metgasco's operations are legal [but] this does not ensure that this company's actions are socially responsible or in the best interests of the local community or the people of New South Wales more generally' (Sommerville, 2014). This distinction permeated the opposition but, importantly, accorded social licence the same status as a legal one, since it was built on democratic norms that all actors - opponents and proponents - seemingly subscribed to.

Poor community consultation and engagement processes are not confined to company behaviour, however. They can be mirrored in political behaviour which reinforces a perception of government bias towards the industry. At a meeting with bureaucratic officials in May 2014, Lismore farmers lamented that they were more knowledgeable and better informed than their official bureaucratic counterparts. They demanded to know why government officials were not adequately monitoring the company's well 'blow-outs' and contaminated water spills. Capturing the mood of the meeting one landholder lamented that:

We are all clear in our understanding of the risks and threats associated with industrialisation of our area and are a very well-informed community, familiar with the plethora of evidence documenting the risks and failures of the gas industry. Yet once again, the government has failed to recognise and address community concerns and call for a stop to gas exploration in the Northern Rivers (in Dobney, 2014).

The landholders' concerns were reinforced by the adverse findings against other gas industry operators that the government had failed to adequately monitor (see Kendall, 2015). Here the government itself was deemed to have failed the democratic test. 


\subsection{Governments and social licence}

Governments are unavoidably implicated in social licence disputes. As the IEA (2012: 49) points out, while 'the ultimate responsibility for sustaining public confidence rests with the industry, it is governments that need to set the regulatory framework, promulgate the required principles and provide [research] support'. Unable to evade issues that are fundamentally political, the resolution to the question of what the most appropriate course of action should be when a company has not 'won' a social licence, is ultimately theirs. Once again, a refusal to involve themselves - even as technically they are not always obliged to - is to expose social licence as a rhetorical strategy to which both the industry and governments subscribe. When contestant communities increasingly invoke social licence's democratic credentials, and support their claims with respected democratic norms, governments are often compelled to act in one manner or other, even if only to protect their political and electoral capital. The assigned role of 'mediator' places governments in invidious positions - caught between their responsibilities to their constituents and those to their corporate clients.

In any case, the community's political messaging directly targeted governments from the outset. One contestant was uncompromising: 'The Northern Rivers community is overwhelmingly opposed to invasive gasfields, and demands that the NSW government acts for its constituents and declares the region Gasfield Free' (Guise, 2014). Indeed, with Metgasco 'on notice that they have no social licence ... [t] he community is outraged that their elected government representatives are not listening to them, and we demand that the state government steps in to stop this toxic industry' (CSGFNR, 2014a). For others, the gas industry clearly 'has no social licence in NSW, yet despite community opposition the state government is pushing ahead with plans to impose this industry on unwilling communities' 
across the state 'by force' (Galliard, 2013). Underscoring the direct politicisation of social licence, and the democratic norms that it invoked, opponents charge that "[t]his issue has now become a real test for local democracy to have this gasfield invasion stopped once and for all'.

This 'democracy' narrative, and the 'social contract' resonances that social licence invoke, resonated deeply within the community:

The Bentley Blockade has been an historic outbreak of democracy in which an entire region has stood up against the combined forces of the State government and the mining industry ... The State government needs to address the fact that our democracy is in crisis. The mining industry has corrupted our political system and the community has lost faith in our parliaments and politicians ... This victory at Bentley puts the issue of community democracy front and centre. It represents a significant victory of people power over vested interests (CSGFNR, 2014b).

The fundamentally democratic character of social licence was even reiterated by conservative members of the Australian parliament who are considered particularly enthusiastic supporters of the gas industry in the area - albeit the Labor Party counterparts have been equally so. On the eve of a pivotal shareholder meeting for Metgasco, a (conservative) Party MP stated that the seeming termination of the unconventional gas industry in the Northern Rivers region is 'democracy in action':

We've just seen the changing landscape for coal seam gas. It was thrust on the Northern Rivers without really any knowledge or understanding of the industry. As communities got to better understand how the industry worked, what it meant for the environment, they rejected it. That's the story of mining - mining is a risky investment (in ABC, 2015). 
This was reinforced by another federal Nationals MP, one whose parliamentary seat was at significant risk, who proclaimed that 'Every man, woman and child who was prepared to say "I do not want this industry in this region for all these reasons" ... stood up, and were heard. This says to the government they need to listen to the community' (in Jeffery, 2015). Others invoked democratic norms more directly, with yet another conservative MP observing that 'I am a democrat. It is very clear to me that the Northern Rivers are resolute in their determination that CSG is not appropriate to their area' (Franklin, 2015).

Regardless of this opposition even from sources the company would have expected support from, the company proceeded to admonish governments for failing to more directly protect the company's legal and commercial rights - that is, to protect tangible legal licence rights against less weighty social licence ones. In a series of letters to the NSW government in 2013, Metgasco's CEO warned that 'exploration and development activity of all kind will come to a stop in NSW if companies who have valid and government approved work programs can have their legitimate activities sabotaged by activists who see themselves as being above the law'; this forced the company to demand 'stronger police action and the imposition of mandatory sentencing of those who are found guilty' (in Broome, 2014). A follow-up letter, on February 6, 2013 to the then energy minister lamented the government's inadequate response to their policing requests and re-stated the urgency of a permanent police presence at the drilling site to contain 'a small, unruly opposition' which would destroy 'resource development and energy supply' in the state if not stopped (in Broome, 2014).

In the end, even after winning its Supreme Court challenge against the NSW government's suspension of its licence and advertising its determination to proceed, the company capitulated in early 2016 by selling its exploration licence back to the NSW government. That this government went so far as to ultimately buy out the company's 
licences in an effort to hasten the industry's exit from the region is not to suggest that this can be the usual expected outcome; indeed it seldom is. But when the 'conditions' are right, the politicisation of social licence, particularly through the utilisation of a potent democracy frame by resourceful contestants, can prove an effective contestation tool.

\section{Conclusion and Policy Implications}

While devoid of the authoritative weight of legal licence, this case has demonstrated that to underestimate the influence of social licence, or to simply treat it rhetorically, is fraught with commercial and political risk. As a central element in the edifice of CSR, social licence has today come to represent the new accountability relationship that communities increasingly demand. While CSR may have been fashioned by corporations as a way of managing or taking charge of challenges in a complex globalised environment, today the CSR and social licence agenda is no longer theirs to fashion alone. This paper has reinforced Crouch's observation that there is today a notable shift from CSR as 'an agenda framed by firms themselves, to notions of corporate responsibility framed by groups of citizens' (2011: 142). This framing of the CSR agenda by 'groups of citizens' has been assisted in our case by an effective construction of a 'master' democratic frame to steer the contestation.

della Porta and Diani (2006, p. 82) aptly ask: '[u]nder what conditions are frames successful'? As we saw, one of the ways social licence has achieved its more strategic status among civil society is through its transformation into an essentially political concept that invokes democratic norms which resonate strongly with much of the population. This paper has argued that the effectiveness of the anti-unconventional gas opposition in the region relied in part on its capacity to cohere a broad range of disparate actors with different political 
and values positions, under the broad frame of 'democracy'. On a strategic level, this approach succeeded in taming any ostensible divisions - greenies 'versus' farmers, radicals 'versus' conservatives, for example - and binding them together under the umbrella of a kind of 'master frame' to which all felt they could subscribe to. Benford (2013) notes that, to be successful, master frames need to be 'elastic, flexible, and inclusive enough' to accommodate and bind disparate actors, as has occurred in our case.

The outcomes in this case raise somewhat of a paradox. While companies have succeeded in placing social licence front and centre of corporate communication in an effort to enhance their reputations as good corporate citizens, it is often the absence of such a licence, and its potential exposure as mere rhetoric, which threatens these same reputations. Moreover, the notion risks a trajectory not intended by its creators. The public may have embraced the notion enthusiastically, but can also conceptualise and utilise it in ways that challenge rather than subscribe to corporate abstractions of it. For mining companies, the purpose of social licence, despite even the most upright intent, is seldom to retire projects for which they have a legal licence if they fail to persuade the community of their safety and benefits. But for many communities this is increasingly what the meaning of social licence is.

The democratic character ascribed to social licence in turn entangles governments in unwelcome disputes underpinned by a narrative which is politically risky for them: the issue of a whole community's perceived disenfranchisement in a supposed democracy where corporate 'bullies' threaten to 'bludgeon' communities into submission, often with compliant governments in tow. Whether accurate or not, this is a powerful narrative that governments, with an eye on their political objectives and political capital, and the modern corporation, with an eye on its reputation and bottom line, will want to avoid. In our case at least, the 
company's narrative of reassurance, delivered through their deployment of social licence, was eclipsed by the community's more resonant democratic one.

\section{References}

Australian Government. 2015a. Energy White Paper. Commonwealth of Australia, Department of Industry and Science. Available at: www.ewp.industry.gov.au Australian Government. 2015b. Energy: Unconventional Gas. Commonwealth of Australia, Department of Industry, Innovation and Science. Available at: http://www.industry.gov.au/Energy/EnergyMarkets/Pages/UnconventionalGas.aspx

Australian Broadcasting Commission (ABC). 2015. 'Metgasco meeting to determine fate of coal seam gas on NSW north coast'. 16 December. Available at: http://www.abc.net.au/news/2015-12-16/metgasco-agm-meeting-north-coast$\underline{\operatorname{csg} / 7032462 \text { ?WT.ac=localnews northcoast }}$

Benford, R.D. 2013. 'Master Frame'. In: Snow, D.A., della Porta, D., Klandermans, B., McAdam, D. (Eds.), The Wiley Blackwell Encyclopedia of Social and Political Movements. Wiley-Blackwell, New York.

Benford, R.D., Snow, D.A. 2000. 'Framing Processes and Social Movements: An Overview and Assessment'. Annual Review of Sociology, 26, 611-639.

Bice, S., Moffat, K., 2014. 'Social licence to operate and impact assessment'. Impact Assessment and Project Appraisal 32 (4), 257-262.

Boutilier, R.,Thomson, I. 2011. 'Modelling and Measuring the Social Licence to Operate: Fruits of a Dialogue Between Theory and Practice.' International Mine Management, Queensland. 
Broome, H. 2014. 'Revealed: Metgasco’s “Missing” Letters to Ministers.' The Northern Star March 12. Available at: http://www.northernstar.com.au/news/revealed-metgasco-bosssecret-ministerial-correspo/2195647/.

Cham, T. 2014. 'Shale gas, coal seam gas ... what's the difference?' CSIRO (Commonwealth Scientific and Industry Research Organisation): CSIRO Blog 30 October. Available at: https://blog.csiro.au/shale-gas-coal-seam-gas-whats-the-difference/

Colvin, R., Witt, B., Lacey, J. 2015. 'The social identify approach to understanding sociopolitical conflict in environmental and natural resources management. Global Environmental Change 34, 237-246.

Cotton, M., Rattle, I., van Alstine, J. 2014. 'Shale Gas Policy in the United Kingdom: An Argumentative Discourse Analysis.' Energy Policy 73, 427-38.

Crouch, C. 2011. The Strange Non-Death of Neo-Liberalism. Cambridge: Polity Press. CSGFree Northern Rivers (CSGFNR). 2014a. Media Release. 'Camp ground at Bentley shows commitment of protectors opposing gasfield industrialisation'. 1 March. Available at: http://csgfreenorthernrivers.org/updatesandevents/mr-camp-ground-at-bentley-showscommitment-of-protectors-opposing-gasfield-industrialisation/

CSGFree Northern Rivers (CSGFNR). 2014b. Media Release. 'People power victory at Bentley blockade'. Media Releasee. 15 May. Available at: http://csgfreenorthernrivers.org/updatesandevents/mr-people-power-victory-at-bentley$\underline{\text { blockade/ }}$

CSIRO (Commonwealth Scientific and Industry Research Organisation). 2014. 'What is Coal Seam Gas?' August. Available at: http://www.csiro.au/Outcomes/Energy/Energy-fromoil-and-gas/UnconventionalGas/Learn-more/What-is-coal-seam-gas.aspx

Davis, C. 2012. "The Politics of "Fracking": Regulating Natural Gas Drilling Practices in Colorado and Texas.' Review of Policy Research 29(2), 177-91. 
della Porta, D. \& Diani, M. 2006. Social Movements: An Introduction. $2^{\text {nd }}$ edition. Blackwell, Oxford.

Dobney, C. 2014. 'Government Suspends Bentley Gas Permit.' Echo NetDaily, May 15. Available at http://www.echo.net.au/2014/05/government-suspends-bentley-gas-permit/ Dunphy, D., Griffiths, A., Benn, S. 2014. Organisational Change for Corporate Sustainability. $3^{\text {rd }}$ Edition. Routledge, London.

Evensen, D., Jacquet, J. B., Clarke, C. E., Stedman, R. C. 2014. 'What's the "fracking" problem? One word can't say it all'. The Extractive Industries and Society 1(2), 130-136.

Forbes, L.C., Jermier, J.M. 2010. 'The New Corporate Environmentalism and the Ecology of Commerce.' Organization \& Environment 23(4), 465-81.

Franklin, B. 2015. Inaugural speech of the Honourable Ben Franklin (to the Parliament of New South Wales). Available at:

https://www.parliament.nsw.gov.au/prod/parlment/members.nsf/0/92f0a06499198a57ca25 7e2a0018e247/\$FILE/Inaugural\%20speech\%20-\%20Ben\%20Franklin.pdf

Gaillard, I. 2012. 'Call on Metgasco Boss to Honour Pledge on Social Licence'. Media Release: CSGFree Northern Rivers. 14 May. Available at: http://csgfreenorthernrivers.org/updatesandevents/call-on-metgtasco-boss-to-honourpledge-on-social-licence/

Gaillard, I. 2013 . 'Activists watch as 'frustration boils over' at Metgasco AGM.' Media Release: Lock the Gate Alliance. 30 October. Available at: http://csgfreenorthernrivers.org/media-releases/activists-watch-as-frustration-boils-overat-metgasco-agm/

Gasfield Free Northern Rivers (GFNR). 2015. Available at http://csgfreenorthernrivers.org/ Gasfield Free Northern Rivers (GFNR). 2016. 'Gasfield Free Communities'. Available at http://csgfreenorthernrivers.org/csg-free-communities/ 
Goffman, E. 1974. Frame Analysis. Harvard University Press, Cambridge, MA.

Goldenberg, S. 2013. 'Fracking Hell: What it's Really Like to Live Next to a Shale Gas Well.' The Guardian, December 13. Available at:

http://www.theguardian.com/environment/2013/dec/14/fracking-hell-live-next-shale-gaswell-texas-us.

Guise, A. 2014. 'Gasfield Free Northern Rivers welcomes the right to say no to invasive gasfields, but it must be legislated'. Media Release: Gasfield Free Northern Rivers. 28 March. Available at: http://csgfreenorthernrivers.org/updatesandevents/mr-gasfield-freenorthern-rivers-welcomes-the-right-to-say-no-to-invasive-gasfields-but-it-must-belegislated/

Gunningham, N., Kagan, R.,Thornton, D. 2004. 'Social License and Environmental Protection: Why Businesses Go Beyond Compliance.' Law and Social Enquiry 29(2), $307-41$.

Hauter, W. 2013. 'For Democrats Nationwide, Pennsylvania Offers a Lens on the Widening Rift Over Fracking.' Huffington Post, September 25. Available at: http://www.huffingtonpost.com/wenonah-hauter/for-democrats-nationwideb $3981518 . h t m l$

Hausfather, Z. 2015. 'Bounding the climate viability of natural gas as a bridge fuel to displace coal'. Energy Policy 86, 286-294.

Hodge, R. A. 2014. 'Mining Company Performance and Community Conflict: Moving Beyond a Seeming Paradox.' Journal of Cleaner Production 84, 27-33.

Honan, K. 2011. 'Metgasco boss says community relationship is essential'. Australian Broadcasting Commission (ABC) Rural. 17 May. Available at: http://www.abc.net.au/site-archive/rural/nsw/content/2011/05/s3219276.htm 
Hutton, D., Connors, L. 1999. A History of the Australian Environment Movement.

Melbourne: Cambridge University Press.

IEA (International Energy Agency). 2015. World Energy Outlook 2015. OECD/IEA, Paris.

IEA (International Energy Agency). 2014. Energy Policies of IEA Countries: The United States. OECD/IEA, Paris.

IEA (International Energy Agency). 2012. The Golden Rules for a Golden Age of Gas: World Energy Outlook: Special Report on Unconventional Gas. OECD/IEA, Paris.

Inglehart, R.1990. 'Values, Ideology, and Cognitive Mobilization in New Social Movements. In: Dalton, R., Kuechler, M. (Eds.), Challenging the Political Order. Polity Press, Cambridge.

Inglehart, R. 1977. The Silent Revolution: Changing Values and Political Styles among Western Publics. Princeton University Press, Princeton.

Jaspal, R., Nerlich, B. 2014. 'Fracking in the UK press: Threat dynamics in an unfolding debate'. Public Understanding of Science 23(3), 348-363.

Jeffery, E. 2015. 'CSG fighters celebrate - Metgasgone?' Echo NetDaily . November 3. Available at: http://www.echo.net.au/2015/11/csg-fighters-celebrate-metgasgone/

Johnson, C., Boersma, T. 2013. 'Energy (In)Security in Poland: The Case of Shale Gas.' Energy Policy 53, 389-99.

Kendall, R. 2015. 'Coal Seam Gas Drags AGL into Troubled Waters.' Ethical Investor, February 4. Available at http://ethicalinvestor.com.au/coal-seam-gas-drags-agl-troubledwaters/.

Kuch, D., Ellem, G., Bahnisch, M., Webb, S. 2013. 'Social License and Communications Report.' Centre for Social Research in Energy and Resources, University of Newcastle, January. Available at 
http://www.acola.org.au/PDF/SAF06Consultants/CSRER\%20ATSE\%20-

\%20Social\%20License\%20Communication\%20Jan\%202013.pdf.

Lock the Gate Alliance. 2016. Lock the Gate. Available at: http://www.lockthegate.org.au/

Luke, H., Lloyd, D. 2013. Report to Lismore City Council on Community Perspectives on Coal Seam Gas Developments. Southern Cross University, Lismore.

Measham, T., Fleming, D., Shandl, H. 2016. 'A conceptual model of the socioeconomic impacts of unconventional fossil fuel extraction'. Global Environmental Change 36, 101110.

Metgasco, 2014a. Community Relations Policy. Available at: http://www.metgasco.com.au/information/community-relations-policy

Metgasco, 2014b. Environmental Policy. Available at: http://www.metgasco.com.au/information/environmental-policy

Metgasco, 2014c. 'Peter Henderson: Setting the Record Straight'. 29 May. Available at http://www.metgasco.com.au/asx-announcements/drilling-suspension-update

Metgasco. 2013. 'Metgasco plans to recommence gas exploration in Northern Rivers NSW'. 2 October. Available at: http://www.metgasco.com.au/asx-announcements/metgascoplans-recommence-gas-exploration-northern-rivers-nsw

Minerals Council of Australia (MCA). 2005. Enduring Value: The Australian Minerals Industry Framework for Sustainable Development. Guidance for Implementation. MCA. July.

Moffat, K., Zhang, Z. 2013. 'The Path to Social Licence to Operate: An Integrative Model Explaining Community Acceptance of Mining.' Resources Policy 39(1), 61-70.

Nicholls, S. 2014. 'Bentley Coal Seam Gas Drilling Suspended, Referred to ICAC.' Sydney Morning Herald May 15. 
O’Faircheallaigh, C. 2013. 'Corporate Social Responsibility'. In Government and Business in Volatile Times. Eds. van Acker, E., Curran, G. Sydney: Pearson.

Owen, J.R., and Kemp, D. 2013. 'Social Licence and Mining: A Critical Perspective.' Resources Policy 38(1), 29-35.

Prno, J. 2013. 'An Analysis of Factors Leading to the Establishment of a Social Licence to Operate in the Mining Industry.' Resources Policy 38(4), 577-90.

Raufflet, E., Barin Cruz, L., Bres, L. 2014. 'An Assessment of Corporate Social Responsibility Practices in the Mining and Oil and Gas Industries.' Journal of Cleaner Production 84, 256-70.

Reinhardt, F. L., Stavins, R.N. 2010. 'Corporate Social Responsibility, Business Strategy and the Environment.' Oxford Review of Economic Policy 26(2), 164-81.

Ricketts, A. 2012. 'The emerging movements against coal seam gas'. Adrian Ricketts Activist. Available at: http://aidanricketts.com/the-emerging-movements-against-coalseam-gas/

Santos, I., Maher, D. 2012. 'Submission on National Greenhouse and Energy Reporting (Measurement) Determination 2012-Fugitive Emissions from Coal Seam Gas.' To Australian Department of Climate Change and Energy Efficiency, Lismore NSW, October 19.

Sledge, S. 2016. 'Metgasgone! But no room for complacency'. The Nimbin Times, January. Sommerville, W. 2014. 'Compelling reasons to suspend Metgasco's operations'. 30 March. Available at: http://creeksbend.com/Dr\%20W\%20Somerville's\%20Response $\% 20$ to $\% 20 \mathrm{Mr} \% 20 \mathrm{Henders}$ on's $\% 2024 \% 20 \mathrm{Mar} \% 202014 \% 201$ etter.pdf

Supreme Court, New South Wales. 2015. Metgasco Limited vs Minister for Resources and Energy. Decision date: 24 April. Citation: [2015] NSWSC 453. 
